\title{
A Methodological Intervention in Cosmopolitanism Research: Cosmopolitan Dispositions Amongst Digital Natives
}

\author{
by Johan Lindell \\ Karlstad Univeristy \\ Sociological Research Online, 19 (3), 19 \\ <http://www.socresonline.org.uk/19/3/19.html> \\ DOI: $10.5153 /$ sro.3418
}

Received: 29 Nov 2013 | Accepted: 19 Jun 2014 | Published: 15 Aug 2014

\begin{abstract}
The concept cosmopolitanism has the potential of becoming one of the most interesting social scientific tools for understanding $\square$ contemporary social life. Operationalising it however, has proved a difficult task. Here, researchers utilise different single indicators while $\square$ making claims towards the same theoretical concept. This not only undermines the theoretical complexity immanent in the term cosmopolitanism, but also creates a false intersubjectivity in the field of cosmopolitanism studies. In order to 'save' cosmopolitanism $\square$ from the risk of becoming an 'empty signifier' (Ekrbis et al. 2004) or a "'free-floating" discursive geist' (ت1/olton 2009), in an attempt to address the 'muddy' (Calhoun 2008) nature of the concept, this paper presents a methodological blueprint that locates the process of definition in the intersection of the theoretical and the empirical. As such, the proposed methodological way of conduct starts on the $\square$ conceptual level in order to define the central theoretical tenets included in the cosmopolitan disposition. It then operationalises these $\square$ claims into indicators that are included in an exploratory analysis of the data set. In conducting a minor quantitative study on 'digital natives' in Sweden the method is illustrated as being able to discern manifestations of 'actually existing cosmopolitanisms' (Malcomson 1998 ) and thus avoid the risk of reductionism involved with the use of one-dimensional indicators or pre-existing, less-than-adequate variables in secondary data.
\end{abstract}

Keywords: Cosmopolitan Disposition, Cosmopolitanism Studies, Methodology, Principal Component Analysis, Survey Research, Digital Natives

\section{Introduction: Towards a Broadened Methodology in Cosmopolitanism Studies}

The multiple origins of, and divergent contemporary discourses on cosmopolitanism (from Greek kosmou politês, literally 'citizen of the world') make it a difficult concept to operationalise for empirical scrutiny. Yet $\square$ researchers interested in the attitudinal and behavioural implications of the major structural transformations in modernity - globalisation and transnationalisation - have tried to climb down the ladder of abstraction and venture into the daunting task of making cosmopolitanism work as a category describing certain outlooks and practices pertaining to social life in the $21^{\text {st }}$ century (see Roudometof 2005; Schueth \& O'Loughlin 2008; Olofsson \& Öhman 2008; Phillips \& Smith 2008; Gustafsson 2009; Nowicka \& Rovisco 2009; Pichler 2009; 2012; Mau 2010).

Here, Roudometof (2005), Phillips \& Smith (2008), Holton (2009) and Skrbis \& Woodward (2011) have expressed dissatisfaction with the fact that there exists no universal definition that allows cosmopolitanism to be $\square$ properly investigated as an actual occurrence in- and between people. This definitional incoherence has led to $\square$ an unfortunate situation where researchers use different operationalisations communicating with the same theoretical concept. There are two obvious reasons for this. Firstly, cosmopolitanism is a highly normative concept and as such, there exist a plethora of theoretical claims as to what is cosmopolitan and what is not. As with any complex social phenomenon, researchers attempting to investigate cosmopolitanism empirically first $\square$ have to immerse themselves into a debate on the conceptual level: already on the pre-empirical level, there is a lack of consensus (see Skrbis et al. (2004) and Kendall et al. (2009) discussions on 'the problem of attribution'). 
Secondly, in quantitative research, the risk of feeding the growing array of indicators and thus reducing the general validity tied to the field of cosmopolitanism studies[] is furthered by the fact that researchers often rely on secondary data, such as the World Values Survey, European Social Survey and the International Social Survey Programme, none of which aim explicitly at measuring cosmopolitanism (Roudometof 2012). While characterised by statistical sophistication (see especially Schueth \& O'Loughlin 2008; Pichler 2012) the problem in these accounts lies in the fact that researchers have to rely on pre-existing indicators that does not live up to the multi-dimensionality inherent in cosmopolitanism. The risk here is that empirical cosmopolitanism studies end up making true the critique that cosmopolitanism is an empty buzzword, signifying everything and thus, nothing. Feeding into this critique, the diversity of definitions being applied leads to divergent, or even contradictory results $\square$ communicated as factual data, which sets in motion a false intersubjectivity within the field of cosmopolitanism $\square$ studies (for example, compare the diverging conclusions in terms of the role of gender in Phillips \& Smith 2008 contra Pichler 2009 and in terms of a 'mediated cosmopolitanism' in Norris \& Inglehart 2009 contra Lindell 2012, 2014). Of course, the different contexts in which individual studies are conducted might explain diverging conclusions but the coherence of the results hardly gains from the fact that different indicators of cosmopolitanism are employed.

1.3 As such, the field of cosmopolitanism studies is in deep need of a methodological solution replacing the tendency to rely on a 'pick-and-choose-methodology' - a rationale which in the long run strongly impedes the concept of cosmopolitanism of being fruitfully used as an analytical category to understand contemporary social life. Qualitative methodologies have ingrained in their very logic the ability to surpass such obstacles, and important work has been done here (see for example Werbner 1999; Lamont \& Aksartova 2002; Szerszynski \& Urry 2006; Skey 2012). However, it is my contention that if quantitative efforts geared toward the study of cosmopolitanism 'from below' (Gilroy 2004) are to be able to map, explain and understand cosmopolitanism in a sophisticated and valid way, a methodological solution addressing the problems described above must come in place.

1.4 Against this background, I want to make a modest suggestion of one such solution. I argue that, methodologically, due to its conceptual complexity, cosmopolitanism is best approached in the intersection of the theoretical and the empirical. I propose a semi-deductive rationale: guided but not limited by theory and ultimately relying on actual manifestations in empirical reality. In essence, the methodological blueprint for quantitative cosmopolitanism research presented here starts on the conceptual level, where theory makes claims as to what makes up the expressions of a 'cosmopolitan disposition' - in which the term 'disposition' designates a 'predisposition, tendency, propensity or inclination' guiding individuals' outlooks and practices (Bourdieu in Kendall et al. 2009: 22; see also Vertovec \& Cohen 2002; Nowicka \& Rovisco 2009). Taken together, the theories are classified according to the overarching claims they make, and as such, they are used to create a working definition guiding the overall direction of research (for examples of such working definitions, see Bolton 2009; Skrbis \& Woodward 2011). Furthermore, instead of 'picking-and-choosing' one theoretical element and labelling it as 'cosmopolitanism', the central argument of the present approach is that all relevant theoretical claims of the constituents of the cosmopolitan disposition should be operationalised. This is where this methodological approach is fundamentally new to the field of cosmopolitanism studies. Others have used several indicators to $\square$ create 'cosmopolitanism-indexes' (see for example Norris \& Inglehart 2009; Riefler \& Diamantopoulos 2009, Pichler 2012) but these accounts are still limited by their reliance on pre-existing indicators that are not flexible $\square$ enough to include all relevant tenets of the cosmopolitan disposition. The manifold of indicators, finally, are correlated internally in the dataset, that is, empirically, in order to find the latent dimensions of 'actually existing' $\square$ (Malcomson 1998) cosmopolitanisms.

1.5 In what follows I provide an example of how such a methodological solution can work when applied in practice, on a real sample. The paper, thus, is a case study of this solution, and as such it follows the narrative pertaining to the proposed approach. The next section, therefore, works on the conceptual level and discovers the major tenets of the cosmopolitan disposition as described in leading theoretical works. The following section, in turn, exemplifies how the theoretical work translates into an exploratory method allowing the revelation of the latent, actually existing cosmopolitan dispositions. This is done via a minor quantitative study on 'digital natives' a population hypothesised as one potential social context in which cosmopolitanism might exist in various forms (see for example Phillips \& Smith 2008; Dahlgren 2012).

1.6 But why this effort to 'save' cosmopolitanism? It is a contested concept, and critics claim that it veils a Eurocentric moral universalism, or a form of Westernisation (see for example Miller 2002; van der Veer 2002). While this may hold true in neo-Kantian theories of world governance (see Archibugi et al. 1998), more grounded social theory brings cosmopolitanism down to the level of actual people and their outlooks and practices. This 
view holds that cosmopolitanism is expressed differently in various social, political, economic, cultural and demographic contexts and, as such, cosmopolitanism is here a post-universalistic analytical category with the potential of advancing new forms of understandings- and pinning down some of the essential traits of contemporary, increasingly global, social life (see Delanty 2009; Kendall et al. 2009). In order to properly extract this potential - in order to save cosmopolitanism from becoming an 'empty signifier' (Ekrbis et al. 2004: 117) what is needed is the diversification of the methodological instruments with which we claim to capture cosmopolitanism: a way to find various manifestations of cosmopolitanism in different contexts..

1.7 I make two basic suppositions in the present paper. Firstly, following Delanty (2009: 13) I argue that cosmopolitanism is best understood when it is not considered something statically pre-defined to the $\square$ methodological level: 'there are cosmopolitanisms rather than one single form of cosmopolitanism' (Kendall et al. 2009). Following Beck (2006), the second supposition is that while the many faces of cosmopolitanism may be the seeds for a fruitful normative debate on the state of the world in the $21^{\text {st }}$ century, 'one can also understand them in an empirical-sociological sense, uncover their internal contradiction and investigate their concrete manifestations' (2006: 7; see also Kendall et al. 2009; Delanty 2009). Pollock et al. (2000) have argued that defining cosmopolitanism for empirical research in absolute ways is an 'uncosmopolitan thing to do' (घ000: 577). On this basis, they have been accused of being anti-empiricist and contributing to making cosmopolitanism a "free-floating' discursive geist" (Holton 2009: 17. Italics in original). This paper locates itself on the one hand in the culturalist line of thinking which holds that defining cosmopolitanism involves a certain risk of reductionism, and $\square$ on the other hand in the empiricist claim that cosmopolitanism becomes meaningless without being anchored in empirical reality. The question at hand then, is not so much if we define cosmopolitanism, but rather $\mathbb{b}^{\mathrm{b}} \mathrm{w}$ we define it. $\square$

\section{Step 1: Mapping The Cosmopolitan Disposition Conceptually}

2.1 In order to guide the creation of indicators that correspond to the multi-dimensional nature of cosmopolitanism, the methodological solution presented here suggests starting on the conceptual level. The central idea here is to take the multitude of theoretical demands on and definitions of the cosmopolitan $\square$ disposition that can be operationalised and employ them as indicators in the empirical study. On the overarching level, this leads to a working definition that pins down the general claim of the ideal typical cosmopolitanism 'from $\square$ below'.

2.2 Here, Diogenes the Cynic (412-323 BC) argued that the cosmopolitan is a person who does not obey any humanly - locally - constructed social convention (Sayre 1938). Later, the Stoics took cosmopolitanism to designate a moral affiliation beyond one's immediate sphere of existence (घussbaum 1997). Kant, on the other hand, elevated hospitality, that is, the welcoming of distant strangers in ones' home, as the individual embodiment of his otherwise macro-politically oriented cosmopolitanism (Kant 1795/2009). Contemporary commentator Turner has suggested that irony is the core virtue of the cosmopolitan, since the 'understanding of other cultures is assisted by an intellectual distance from one's own national or local culture' (2002: 57). The distancing from the local context of living is also emphasised by Roudometof (2005) who argues for a definition of cosmopolitanism based on a cosmopolitan-local continuum where cosmopolitans are less attached to locality and nation, and display a low degree of economic, cultural and institutional protectionism compared to 'locals' (2005: 125-126; see also Stevenson 2002). Since Roudometof's operationalisation informs a certain type of 'footloose' cosmopolitanism it opposes the idea that people can be tied to a place and yet still be cosmopolitan or in Beck's words to 'have roots and wings at the same time' (Beck 2002: 19) and that cosmopolitanism is 'built on top of local belonging' (Kendall et al. 2009: 39).

2.3 Other definitional attempts draw on Hanna Arendt's concept of 'worldliness' as a particular mode of $\square$ 'being in the world' characterised by self-reflexivity, a heightened care for the world and a certain set of skills $\square$ exhibited in the engagement with the world (Arendt in Smith 2007: 44-45). Others have argued that a general 'attitude of openness' is key to unravelling a sociologically grounded cosmopolitanism and that this would be a potential 'wellspring' of a general definition of a cosmopolitan disposition ధKendall et al. 2009: 113; see also Holton 2009; Skrbis \& Woodward 2011).

2.4 Following this line of thinking I argue that, precisely because of its open-ended nature, a fruitful starting point in creating a working definition of a cosmopolitanism 'from below' is to elevate 'openness' to the 'trans- $\square$ cultural' or global level (Holton 2009: 117; see also Kendall et al. 2009; Skrbis \& Woodward 2011). In order to further classify the tenets of a cosmopolitan disposition I turn to Delanty's (2009) argument that the shift from a 'classical' to a 'contemporary' cosmopolitanism has left cosmopolitanism a moral, political and cultural 
phenomenon (2009: 54-68). While potential overlaps between these dimensions are relevant questions to both theoretical reasoning and empirical scrutiny, they serve an analytical purpose in categorising various claims and drawing the basic contours delineating various dimensions of a cosmopolitan disposition. Furthermore, these three dimensions are often immanent to contemporary theoretical definitions and operationalisations of the $\square$ indicators that the cosmopolitan subject is expected to live up to. For Saito (2011) the three dimensions of cosmopolitanism, brought down onto the individual level, break down as involving the elements of 'cultural omnivorousness, ethnic tolerance, and cosmopolitics' (Saito 2011: 129). For Held (2010), the cosmopolitan disposition (for him 'cultural cosmopolitanism') is made up of an awareness of the interconnectedness of different political communities, the recognition of 'collectives fortunes' that require collective solutions and the 'celebration of difference' (2010: 112). But going into detail - what are the tenets of each dimension, as described in leading theoretical work?

\section{The moral tenets of a cosmopolitan disposition}

Much of the moral demands put on the cosmopolitan today derive from Stoic moral philosophy. For them, the scope of moral affiliation was thought of as making up several concentric circles surrounding the $\square$ individual: the closest and thus most relevant moral 'circle' surrounds the self, then comes family, friends, one's neighbourhood and finally the human community at large. The point here, as made by Seneca (in Dussbaum 1997), is to draw the outer circles closer towards the self and thus expand one's moral geography 'beyond those to whom we are related by the ties of kith and kind' (Appiah 2006: xiii). This notion further materialises in Nussbaum's (1994) rally for a 'cosmopolitan education'. The purpose of institutionalising such a programme is that it helps people to 'recognize humanity wherever she encounters it, undeterred by traits that are strange to her, and be eager to understand humanity in its 'strange' guises' (ibid). To this characteristic belongs Kant's (1795/2009) call for universal hospitality, to be practiced towards visiting strangers, Delanty's expectation that the cosmopolitan should have the capacity of 'positive recognition of the Other' (Delanty 2009: 86) and Beck's demand for 'cosmopolitan empathy' as part of the wider cosmopolitan outlook (2006: 7). Likewise, Chouliaraki $(2006 ; 2013)$ argues that cosmopolitanism in this sense is cultivated at certain times of mediation, as moral concern and emotion is directed to the 'distant sufferer'.

\section{The political tenets of a cosmopolitan disposition}

2.6 Usually, political cosmopolitanism refers more or less directly to the kind of formal, 'from above' and neoKantian cosmopolitanism to be found in, for instance, Held's (2010) principles for cosmopolitan democracy (see also Archibugi et al. 1998). In such views, inquiries on cosmopolitanism revolve around forming principles for the purpose of the 'protection and nurturing of each person's equal significance in 'the moral realm' of humanity' (日eld 2010: 69). More importantly on the sociological level, however, where cosmopolitanism is thought of as a disposition, is the demand that the cosmopolitan individual should be in favour of macro political integration as 'an attempt to establish a wider community' (Pichler 2008: 1122). As such cosmopolitans display an awareness of both 'global risk society' (Beck 2006) and the 'interconnectedness of different political communities' (Held 2010). From such an awareness cosmopolitans must have the capacity to 'create a shared normative culture' (Delanty 2009: 86) and from this realisation he or she should recognise humanity's collective fortunes and the adequate collective solutions (Held 2010). Thus, at the core of the political dimension of a cosmopolitan disposition is the attempt at making 'cosmopolis' a reality by, for example, working for international human rights or attempting to impede global poverty (Smith 2007; Van Hooft 2007). In empirical research, these traits have been operationalised by defining political cosmopolitans as those people who display high levels of trust in $\square$ supranational political forms of governance and those who recognise that there exist problems in the world that can only be resolved from a global political entity (see Norris \& Inglehart 2009; Mau 2010; Saito 2011; Lindell 2012).

\section{The cultural tenets of a cosmopolitan disposition}

2.7 The cultural tenets of a cosmopolitan disposition in turn, can be divided into three separate but interrelated realms. Firstly, there is the most evident tenet of displaying a 'willingness to engage with the Other' (Hannerz 1990: 236; cf. Appiah 2006):

\footnotetext{
/. . ./ cosmopolitanism in a stricter sense includes a stance toward diversity itself, toward the coexistence of cultures in the individual experience. A more genuine cosmopolitanism is first of all an orientation, a willingness to engage $\square$ with the Other. (Hannerz 1990: 239)
}

2.8 To this first notion of cultural cosmopolitanism belong Szerszynski \& Urry's (ஐ002) curiosity, appreciation 
and openness about many places, peoples and cultures and the willingness to take 'risks by virtue of encountering the other' (ibid) and Gilroy's (2004) demotic cosmopolitanism displayed by those who 'find civic and $\square$ ethical value in the process of exposure to otherness' (2004: 75). Beck also stresses that the cosmopolitan should display a 'curiosity of the culturally different' (2006: 7) and Held highlights a 'celebration of difference' (Held 2010: 112).

2.9 Secondly, to the cultural sphere of cosmopolitanism belong also certain aspects of cultural reflexivity, $\square$ irony and knowledge. Merton (1968) stressed the sensation of belonging to 'Greater society' and Schueth \& O'Loughlin (2008) as well as Pichler (2012), emphasises identification with the category of 'citizen of the world' or $\square$ feeling a 'belonging to the world as a whole'. Gilroy (2004) and Delanty (2009) holds that the capacity to relativise one's own culture and to mutually evaluate different cultures are core dynamics in the cosmopolitan disposition whilst Turner (2002) and Smith (2007) put emphasis on irony and distance to one's local culture. In this sense, Szerszynski \& Urry (2002) highlight the ability to map one's own society and its culture in a geographical and historical setting and Kendall et al. (2009) emphasise the capacity of 'cultural code-switching' (Kendall et al. 2009: 111).

2.10 Thirdly, it is argued that cosmopolitanism is often expressed in 'banal, often commercially exploited, processes' (Jansson \& Andersson 2011: 4) as a non-reflexive habitus (日olton 2009). For Szerszynski \& Urry (2002) this includes the mere consumption of many places and cultures. Holton, in turn, emphasises the possibility of a cosmopolitan openness as a taken-for-granted feature of everyday life fostered by globalisation and other latent structures enabling 'cosmopolitan conversation' (2009: 32).

2.11 This expose over the central theoretical descriptions of the cosmopolitan creates a matrix that sums up the essential demands that theory puts on the constituents of a cosmopolitan disposition (see Table 1). At this point then, a working definition that guides the overall expectations in the ensuing research emerges from the $\square$ different theoretical tenets of the cosmopolitan disposition. The working definition, and the ideal type $\square$ cosmopolitan would display a worldly openness across moral, political and cultural dimensions in both outlooks and practices (cf. Holton 2009; Skrbis \& Woodward 2011; Lindell 2014). By all means, the matrix guiding the operationalisation of many indicators is not exhaustive, and the inclusion of other tenets will only strengthen the approach as a whole. In order fulfil the relocation of the process of definition in the intersection of the theoretical $\square$ and the empirical, it is now time to venture into the empirical realm.

Table 1: The Moral, Political and Cultural Tenets of the Cosmopolitan Disposition

\begin{tabular}{ll}
\hline Realm & \multicolumn{1}{c}{ Indicators } \\
\hline Political tenets of & 'the capacity to create a shared normative culture' (Delanty 2009: 87) \\
cosmopolitan & 'an awareness of global risks and the global 'community of fate' Beck \\
disposition & $2006: 7)$ \\
- & 'the impossibility of living in a world society without borders' (ibid) \\
- & Awareness of the interconnectedness of different political communities \\
& (Held 2010: 112) \\
- & A recognition of 'collective fortunes' which require collective solutions \\
& (ibid) \\
- & Trust in supranational institutions (Norris \& Inglehart 2009; Mau 2010) \\
- Willingness to expand political community (Pichler 2008) \\
- Low degree of economic, cultural and institutional protectionism \\
(Roudometof 2005: 126) \\
- Desire to make the world more 'cosmopolitan', e.g. campaigning for \\
human rights, to protect against global poverty (Smith 2007: 46; Van \\
Hooft 2007)
\end{tabular}


Moral tenets of - Learning to recognise humanity wherever it is (Nussbaum 1994; Appiah

cosmopolitan 2006; see Stoic cosmopolitanism)

disposition - Universal hospitality (Kant 1795/2009)

- 'the capacity of positive recognition of the Other' (Delanty 2009: 86)

- 'the experience of cosmopolitan empathy' (Beck 2006: 7)

- Feeling pity and acting on images of distant suffering Chouliaraki 2006, 2013)

- Feeling global responsibility (Nussbaum 1997; Van Hooft 2007)

Cultural tenets of 'the capacity of relativisation of one's own culture' Delanty 2009: 86; cosmopolitan Gilroy 2004: 75)

dispositions

- 'the capacity for a mutual evaluation of cultures of identities' (ibid)

- The consumption of many places and environments (Szerszynski \& Urry 2002)

- Curiosity about many places, peoples and cultures. An openness to and appreciation of other people and cultures (ibid). A curiosity of the culturally different (Beck 2006: 7)

- A willingness to take risks by virtue of encountering the 'other' (Szerszynski \& Urry 2002)

- The ability to 'map' one's own society and its culture in terms of a historical geographical knowledge (ibid).

- All local ethnic religious and cosmopolitan cultures and traditions interpenetrate (Beck 2006: 7)

- Transcultural 'code-switching' (Kendall et al. 2009: 111)

- Inclusive valuing of the culturally other (ibid: 112-113)

- Celebration of difference (Held 2010: 112)

- Willingness to engage with the Other (Hannerz 1990; Norris \& Inglehart 2009; Appiah 2006)

- Not attached to local context of living, state or country and low degree of affiliation with local culture (Boudometof 2005: 26).

- Ironic distance to locality, nation, culture (Turner 2002; Smith 2007)

- The sensation of belonging to 'Greater society' or 'the world' (Schueth \& O'Loughlin 2008; Pichler 2012)

\section{Step 2: Finding Actually Existing Cosmopolitanisms in Empirical Reality}

3.1 The first step in illustrating the proposed methodological rationale has been completed: at our disposal $\square$ are now a variety of theoretical tenets of the cosmopolitan disposition. The central argument I want to make with this paper is that these tenets cannot be individually operationalised into indicators and used to capture the complex concept of cosmopolitanism on their own. Doing so simply reproduces a 'pick-and-chose-methodology' that ignores the theoretical complexity inherent in the term. Thus, in order to make useful the array of theoretical tenets of the cosmopolitan disposition, and to be able to locate 'actually existing cosmopolitanisms' (Malcomson 1998) in a more thorough and valid way, the methodological solution presented here insists that these tenets are all operationalised into indicators and applied on empirical reality, where their latent, multi-dimensional manifestations will be revealed (see Appendix for an overview of the indicators used). In this section this will be illustrated with a minor quantitative study that looks into how cosmopolitanism is manifested amongst 'digital natives'. In line with the aim of the paper (to advance methodological thinking in the field of cosmopolitanism $\square$ studies) the sample of 'digital natives' is here used to illustrate how the suggested methodological solution can be applied in empirical reality.

\section{Illustrating the methodological solution: cosmopolitanisms among digital natives}

3.2 In the survey method applied here, the 'meeting' of the theoretical and the empirical occurs when the indicators derived from the conceptual level are deployed in an exploratory manner on a sample. Derived from the conceptual mapping of the cosmopolitan disposition (Table 1) the indicators are synthesized statements using rating scales inspired by the Likert scale through which respondents were asked to indicate to what extent 
The variable-battery then, works in such a way that a respondent agreeing (by indicating a high number on the scale) with the statement 'I can imagine myself giving financial support to a child in another part of the $\square$ world' not only indicates a moral orientation in the sense that one sets out to help 'distant others' (cf. Chouliaraki 2006 ; 2013) but also a political willingness to change the world beyond one's local context of living for the better (cf. Smith 2007). To use another example, the notion of 'feeling at home in the world' corresponds to the culturalexistential claims of cosmopolitanism made by Merton (1968) and Pichler (2012). Similar logics apply to all indicators: guided by the conceptual matrix presented above, they are all statements posed to the respondents with the intentions of capturing one or several elements of a cosmopolitan disposition (see Appendix). The indicators used, it should be stressed again, do not exhaust the plethora of theoretical claims of the constituents of a cosmopolitan disposition but they do, I argue, make up a basic methodological blueprint that, by way of meta-empirical exploration, is apt for capturing various manifestations of cosmopolitanisms 'from below' and 'uncover their internal contradiction and investigate their concrete manifestations' (Beck 2006: 7). It should also be noted that respondents' 'self-evaluation' that is immanent in survey research risk generating acquiescent response patterns, especially amongst certain groups, meaning that the researcher risk being left investigating a self-referential 'class consciousness' (Calhoun 2002) rather than 'actually existing' cosmopolitanisms Malcomson 1998). Therefore, in order to sustain reliability in this methodological solution the scales were varied in the actual survey, in the sense that some of the statements were posed in an 'anti-cosmopolitan' way whereas some were posed positively, in a 'cosmopolitan' way.

3.4 In order to practically illustrate the affordances of the methodological blueprint presented here, the indicators were deployed in the form of a questionnaire on a small sample of a population categorised as 'digital natives' $(n=65)$ in a mid-sized city in Sweden during the fall of 2012. The term 'digital natives' is used to designate those:

/. . . / born after 1980, when social digital technologies, such as Usenet and bulletin systems, came online. They all have access to networked digital technologies. And they all have the skills to use those technologies. (Palfrey \& Gasser 2008: 1).

3.5 The sample 'digital natives'[2] is characterised by high media and technology penetration and low age ( $M$ $=21$ years old) - every person within the sample owns a personal computer and a Smartphone, all of them having access to the Internet. In the present context the two traits - low age and high media penetration - are both factors implicitly and explicitly hypothesised as related to cosmopolitan dispositions (see Rantanen 2005; Phillips \& Smith 2008; Norris \& Inglehart 2009; Pichler 2009, 2012; Mau 2010; Dahlgren 2012). On a theoretical level, results illustrating how young people are more likely to be cosmopolitan correspond to Western cultural notions that exploration and an openness to the world belongs to the youth and that enclosure and protectionism, on the other hand, comes with age. As for the relation between media consumption and use of technologies of communication, the potentialities lie within the capacity to expand the life-worlds: the world is brought to our front door to create a kind of 'global mediated communion' (Robertson 2010):

\footnotetext{
Over the past decade, audiences across the planet have watched together as people lost their homes and lives in terrorist attacks and natural catastrophes, as Obama placed his hand on Lincoln's Bible, as Neda died on the streets of Teheran, as diplomats blushed then paled in the face of serial Wikileaks disclosures, and as legions of athletes and musicians competed in the Olympic games, World Cup football and the Eurovision song contests. Such global mediated communication is a central feature of the process which, according to Beck (2006), is making people cosmopolitans 'by default'. (Robertson 2012: 178).
}

3.6 Furthermore, Rantanen (2005) holds that if cosmopolitanism is about different ways of relating at a distance then media and communication become central factors - for how can attachments be created at a distance if not via media and communication? (2005: 120). As such, one can expect the sample of 'digital natives' to be a part of one context in which various cosmopolitan dispositions should be manifested. The crucial question then becomes how it is manifested in this particular sphere of society.

3.7 In order to find the 'actually existing' forms of cosmopolitanisms in the sample, a Principal Component $\square$ Analysis (PCA), in which every relevant indicator was included, was run. Simply put, the PCA works to find the latent components - or dimensions - that are 'hidden' in the relations between single variables, or indicators (see de Vaus 2002; Barmark 2009). As such, it is a suitable approach when trying to empirically analyse complex phenomena that would be difficult to grasp with only one indicator. Consequently, the output of the PCA shows $\square$ the internal correlations and contradictions amongst the indicators operationalised to capture various manifestations of cosmopolitan dispositions. In other words the latent dimensions revealed in the PCA output are 
the forms of 'actually existing cosmopolitanisms' (Malcomson 1998) manifested in this particular context of digital natives (see Table 2).

3.8 In Table 2 below, six individual dimensions of the cosmopolitan disposition have emerged within the sample (which displays a Kaiser-Meyer-Olkin-value of .61 indicating fair sampling adequacy). Among these, the first three explain more than $10 \%$ of the variance and include several strong loading scores[3]. Again, it should be stressed, the main purpose of this analysis is to illustrate a methodological way of conduct that, if applied, contributes to enhancing the general validity within the field of cosmopolitanism studies. While the results $\square$ generated here can be seen as proposed contours of cosmopolitanism manifested amongst digital natives in Sweden, they are, because of the relatively small convenience sample not applicable to the entire population.

Table 2. Dimensions of Cosmopolitan Dispositions among Digital Natives 


\begin{tabular}{|c|c|c|c|c|c|c|}
\hline & $\begin{array}{l}\text { 'Strong } \\
\text { cross- } \\
\text { sectional } \\
\text { cosmo- } \\
\text { politanism' }\end{array}$ & $\begin{array}{l}\text { 'Practical- } \\
\text { cultural } \\
\text { cosmo- } \\
\text { politanism' }\end{array}$ & $\begin{array}{l}\text { 'Weak inter- } \\
\text { sectional } \\
\text { cosmo- } \\
\text { politanism' }\end{array}$ & $\begin{array}{l}\text { 'Existential } \\
\text { cosmo- } \\
\text { politanism' }\end{array}$ & $\begin{array}{l}\text { 'Enclosed } \\
\text { political } \\
\text { cosmo- } \\
\text { politanism' }\end{array}$ & $\begin{array}{l}\text { 'Banal } \\
\text { global- } \\
\text { ism' }\end{array}$ \\
\hline $\begin{array}{l}\text { Contributing to } \\
\text { global humanitarian } \\
\text { causes }\end{array}$ & .71 & .10 & .20 & -.04 & -.04 & -.11 \\
\hline $\begin{array}{l}\text { Having contacts in } \\
\text { the world }\end{array}$ & .49 & .37 & 41 & .13 & -.30 & .17 \\
\hline $\begin{array}{l}\text { Feeling empathy for } \\
\text { distant sufferers }\end{array}$ & .80 & .03 & $-13^{-}$ & -.05 & 28 & .09 \\
\hline $\begin{array}{l}\text { Daily consumption } \\
\text { of international } \\
\text { culture }\end{array}$ & $-.0 \overline{6}^{-}$ & -.10 & .05 & -.11 & -.03 & .95 \\
\hline $\begin{array}{l}\text { Support in world } \\
\text { politics }\end{array}$ & .06 & -.10 & .88 & -.11 & .16 & $.0 \overline{3}$ \\
\hline $\begin{array}{l}\text { Immigration } \\
\text { enriches local } \\
\text { culture }\end{array}$ & .41 & .70 & $-.00^{-}$ & .02 & .03 & .18 \\
\hline $\begin{array}{l}\text { Inclined to live in a } \\
\text { developing country }\end{array}$ & .50 & .38 & .22 & .18 & .05 & .00 \\
\hline $\begin{array}{l}\text { Inclined to be } \\
\text { benefactor to a } \\
\text { child in a } \\
\text { developing country }\end{array}$ & .77 & $-.0 \overline{2}$ & .09 & .26 & .23 & -.03 \\
\hline $\begin{array}{l}\text { Inclined to buy 'fair } \\
\text { trade' }\end{array}$ & .64 & -.08 & -.15 & -.19 & -.20 & -.13 \\
\hline $\begin{array}{l}\text { Feeling that the } \\
\text { world is small and } \\
\text { graspable }\end{array}$ & -.13 &.$\overline{8}$ & .50 & .42 & $-.4 \overline{2}$ & -.02 \\
\hline $\begin{array}{l}\text { Local culture not } \\
\text { superior }\end{array}$ & -.25 & .85 & -.09 & -.04 & .05 & -.11 \\
\hline $\begin{array}{l}\text { Engagement in } \\
\text { global crises and } \\
\text { catastrophes }\end{array}$ & 34 & .52 & 31 & -36 & .07 & -35 \\
\hline $\begin{array}{l}\text { Ideological support } \\
\text { in EU }\end{array}$ & .09 & .09 & .11 & .03 & .88 & $=.04$ \\
\hline $\begin{array}{l}\text { Feeling at home in } \\
\text { the world }\end{array}$ & .06 & -.04 & -.06 & .91 & .03 & -.11 \\
\hline $\begin{array}{l}\text { Explained varianœ } \\
(\%)\end{array}$ & 21.50 & 13.80 & 10.37 & $\overline{9} . \overline{3}$ & 8.86 & 8.20 \\
\hline
\end{tabular}

Comment: Principal Component Analysis with Varimax rotation, the numbers indicate strength (Pearson's $r$ ) of each indicator to each component (latent dimension). Values have been rounded up to two decimals.

3.9 Essentially, the results displayed in Table 2 exemplify a methodological alternative to the 'pick-andchoose-methodology' that has been prevalent within quantitative research in the field of cosmopolitanisms $\square$ studies. It shows that when multiple indicators are brought into empirical reality, they reveal the latent, actually existing dimensions of cosmopolitanism that accounts for the theoretical complexity of cosmopolitanism. Here, one sees that, amongst the sample of the 'digital natives' that there exists an almost archetypical form (for 
theoretical comparisons, see Held 2010; Saito 2011) of cosmopolitan disposition (component 1) which corresponds to the ideal typical cosmopolitan derived from the working definition pinning down the cosmopolitan $\square$ disposition as a worldly openness across moral, political and cultural dimensions in both outlooks and practices

3.10 While the strong cross-sectional cosmopolitanism displayed in component 1 was particularly manifest in moral cosmopolitanism, component 2 reveals another strong form of cosmopolitan disposition, less informed by moral outlooks and more by practical-cultural traits such as the capacity to relativise local culture (as emphasised by Gilroy 2004; Delanty 2009). Component 3 is very much a weaker form of the kind of intersectional cosmopolitan disposition displayed in component 1. Components 4 through 6 explain less than $10 \%$ of the variance and thus they should be approached merely as contours of potential expressions of cosmopolitan dispositions. As such, component 4 reveals an interesting existential-cultural cosmopolitanism - a kind of meaningful yet banal cosmopolitanism. Here, none of the moral and political ideals of cosmopolitanism are embodied: engagement in global crises even has a negative relation in this dimension. However, there is a strong sense of belonging to the world as a whole, coupled with the notion that the world feels like a small and graspable place (see also Merton 1968; Holton 2009). Component 5, on the other hand, feeds into Beck's R006) statement that approaching cosmopolitanism in an empirical way reveals its internal contradictions. These are the people living in a large, ungraspable and unknown world that, they feel, is in need of macro-political taming (strong ideological support for the European Union). Component 6, finally, displays one effect of the kind of 'banall globalism' or 'banal cosmopolitanization' (see also Szerszynski \& Urry 2002, 2006; Beck 2006) whereby everyday life is saturated by impressions from near and far: in this dimension the rationale seems to be to consume globally, but not to think or act globally. As such, this dimension raises important questions regarding the relationship between cosmopolitan practice and outlook in an era of 'post-humanitarianism' (Chouliaraki 2013; see also Phillips \& Smith 2008).

\section{Conclusion}

4.1 Starting in the intersection of the culturalist critique that argues that operationalising cosmopolitanism involves a certain amount of reductionism and the empiricist claim that cosmopolitanism becomes meaningless without being related to empirical reality, I have in this paper presented a methodological blueprint for the conduct of survey research dealing with a cosmopolitanism 'from below' (Gilroy 2004) - a 'cosmopolitan disposition' (Skrbis et al. 2004; Kendall et al. 2009). The aim has been to present a solution that can strengthen the ability to reach high validity in quantitative research within the field of cosmopolitanism studies. Thus, the solution puts $\square$ emphasis on how researchers should approach the problem of definition inherent in the concept of cosmopolitanism (as defined by Bkrbis et al. 2004; Kendall et al. 2009). As such, I have argued that cosmopolitanism is best approached in the intersection of the theoretical and the empirical. I propose starting by operationalising the many theoretical demands on the cosmopolitan disposition into a manifold of indicators, in order to then analyse them meta-empirically so as to find latent, multi-dimensional components. The affordances $\square$ of this approach were illustrated by a minor quantitative study on 'digital natives' that revealed the actually existing dimensions of cosmopolitanisms within a given context. This methodological solution puts high demands on the data because, in practice, it involves the researcher deploying batteries of variables able to capture the conceptual diversity and complexity inherent in cosmopolitanism. While the technicalities and the general rationale guiding this methodological blueprint is far from new, its adoption, and the form in which it has been presented here is novel to the field of cosmopolitanism studies. The ensuing step, of course, is to apply the $\square$ presented method on a larger sample and to pursue the construction of indexes from the revealed dimensions, and to contextualise them further by putting them into relation with different 'independent' variables.

4.2 Critical commentators might suggest that the concept of cosmopolitanism is a new, empty buzzword, describing everything and nothing. Such critique does not materialise out of thin air. It is, however, my conviction that with the proper methodological rationale the concept of cosmopolitanism has the potential of becoming one of the most interesting tools through which the social sciences can understand social life in the $21^{\text {st }}$ century.

Appendityere, the indicators used in the PCA are displayed. Please note that since the data was collected in Sweden, the questions have here been translated into English. Also, note that some of the statements were posed in reversed, 'negative' ways so as to avoid acquiescent response patterns.

'Below you will find a number of statements. Please mark the number between 1 (I don't agree at all) and 10 (I agree completely) which best fits your position.' $\square$ 
- I am actively contributing to global humanitarian causes (for example by donations, voluntary work).

- Generally speaking, I have many contacts in other parts of the world.

- I empathise with exposed and vulnerable people in other parts of the world.

- I consume international culture on a daily basis.

- There are problems in the world that can only be solved by international cooperation.

- Immigration enriches cultural life in Sweden.

- I can imagine living for a longer period of time in a developing country.

- I can imagine giving financial support to a child in another part of the world. $\square$

- I prefer 'fair trade' groceries to the regular range of groceries.

- The world feels small and graspable.

- Swedish culture is not superior to any other culture.

- I am engaged in global crises and catastrophes.

- The European Union is in essence a good project.

- I feel at home in the world.

\section{Notes}

Cosmopolitanism has gained enormous interdisciplinary interest throughout the last two decades.

Following Delanty's Routledge Handbook of Cosmopolitanism Studies (2012), it is therefore useful for the purposes of this paper to take 'cosmopolitanism studies' to designate the interdisciplinary field dedicated to the $\square$ study of cosmopolitanism.

Here, it is important to note that the concept 'digital natives' has been subject to critique because of its tendency to assume that age (or generation) would be the most important (or the only) factor in determining the capacities according to which people appropriate 'networked digital technologies' (for critique see for example Selwyn 2009; Helsper \& Eynon 2010). In this study I use the concept 'digital natives' to designate young people with access to 'networked digital technologies' as such, I do not make any inquiries into the validity of the term outside this particular definition. $\square$

In order for a component to be relevant, it should explain a certain portion of the total variance between all the variables included in the analysis. A usual threshold value is $10 \%$.

\section{References}

APPIAH, K.A. (2006) Cosmopolitanism: Ethics in a World of Strangers Penguin Books.

ARCHIBUGI, D., Held, D., \& Köhler, M. (eds). (1998)Re-imagining Political Community: Studies in Cosmopolitan Democracy. Stanford: Stanford University Press.

BARMARK, M. (2009) 'Faktoranalys', in Djurfelt, G \& Barmark, M (Eds)Statistisk Verktygslåda 2 - Multivariat Analys. Lund: Studentlitteratur.

BECK, U. (2002) 'The Cosmopolitan Society and its' Enemies',Theory, Culture \& Society Vol. 19, Issue 1-2: p.17-44. [doi://dx.doi.org/10.1177/026327640201900101]

BECK, U. (2006) The Cosmopolitan Vision. Cambridge: Polity Press.

CALHOUN, C. (2002) 'The Class Consciousness of Frequent Travellers: Toward a Critique of Actually Existing Cosmopolitanism', The South Atlantic Quarterly Vol. 101, Issue 4: p.869-897. [doi://dx.doi.org/10.1215/00382876-101-4-869]

CALHOUN, C. (2008) 'Cosmopolitanism and the Modern Social Imaginary', Daedalus Vol. 137, Issue 3: p.105113. [doi://dx.doi.org/10.1162/daed.2008.137.3.105]

CHOULIARAKI, L. (2006) The Spectatorship of Suffering. London: Sage.

CHOULIARAKI, L. (2013) The Ironic Spectator: Solidarity in the age of Post-humanism Cambridge: Polity Press. 
DAHLGREN, P. (2012) 'Online Journalism and Civic Cosmopolitanism: Professional vs. Participatory Ideals', Journalism Studies, iFirst Article: p.1-16.

DE VAUS, D.A. (2002) Surveys in Social Research Allen \& Unwin. [doi://dx.doi.org/10.4135/9781446263495]

DELANTY, G. (2009) The Cosmopolitan Imagination: The Renewal of Critical Social Theory. Cambridge: Cambridge University Press.

DELANTY, G (Ed). (2012) The Routledge Handbook of Cosmopolitanism Studies. London, New York: Routledge.

GILROY, P. (2004) After Empire: Melancholia or Convivial Culture?. London: Routledge.

GUSTAFSSON, P. (2009) 'More Cosmopolitan, No Less Local: The Orientations of International Travellers', European Societies Vol. 11, Issue 1: p.25-47. [doi://dx.doi.org/10.1080/14616690802209689]

HANNERZ, U. (1990) 'Cosmopolitans and Locals in World Culture', Theory, Culture \& Society Vol. 7, Issue 2: p.237-251. [doi://dx.doi.org/10.1177/026327690007002014]

HELD, D. (2010) Cosmopolitanism: Ideals, Realities and Deficits[Cambridge: Polity Press.

HELSPER E.J. \& Enynon, R (2009). 'Digital Natives - Where is the Evidence?', British Educational Research Journal Vol. 36, Issue 3: p.3-20.

HOLTON, R. (2009) Cosmopolitanisms: New Thinking and New Directions Palgrave McMillan.

JANSSON, A. \& Andersson, M. (2011) 'Mediatization at the Margins: Cosmopolitanism, Network Capital and Spatial Transformation in Rural Sweden'. Paper presented at International ACSIS Conference, Norrköping, 15-17 June 2011.

KANT, I. (1795/2009) Den Eviga Freden (translated by Alfred W. Johansson). Stockholm: Nordstedts Akademiska Förlag.

KENDALL, G., Woodward, I. \& Skrbis, Z. (2009) The Sociology of Cosmopolitanism: Globalization, Identity, Culture \& Government. New York: Palgrave McMillan. [doi://dx.doi.org/10.1057/9780230234659]

LAMONT, M. \& Aksartova, S. (2002) 'Ordinary Cosmopolitanisms: Strategies for Bridging Racial Boundaries among Working-class Men', Theory, Culture \& Society Vol. 19, Issue 4: p.1-25. [doi://dx.doi.org/10.1177/0263276402019004001]

LINDELL, J. (2012) 'Beyond Distant Suffering and Pity-compelled Cosmopolitanism - Examining the Relation Between the Consumption of Ordinary News, General Media Consumption and Cosmopolitan Outlooks in Scandinavia', Observatorio Vol. 6, Issue 1: p.47-62.

LINDELL, J. (2014) Cosmopolitanism in a Mediatized World: The Social Stratification of Global Orientations $\square \mathrm{PhD}$ Dissertation. Karlstad: Karlstad University Press.

MALCOMSON, S. (1998) 'The Varieties of Cosmopolitan Experience' in Cheah, P., \& Robbins, B (Eds) Cosmopolitics: Thinking and Feeling Beyond the Nation. Minneapolis: Minnesota University Press.

MAU, S. (2010) Social Transnationalism: Life-worlds Beyond the Nation-state. London \& New York: Routledge.

MERTON, R. (1968) Social Theory and Social Structure. New York: Free Press.

MILLER, D. (2002) 'Cosmopolitanism: A Critique', Critical Review of International Social and Political Philosophy Vol. 5, Issue 3: p.80-85. [doi://dx.doi.org/10.1080/13698230410001702662]

NORRIS, P. \& Inglehart, R. (2009) Cosmopolitan Communications: Cultural Diversity in a Globalized World New York: Cambridge University Press. [doi://dx.doi.org/10.1017/CBO9780511804557]

NOWICKA, M. \& Rovisco, M (eds). (2009) Cosmopolitanism in Practice. Ashgate.

NUSSBAUM, M.C. (1994) 'Patriotism and Cosmopolitanism' in Boston Review 19(5). Retrieved from http://bostonreview.net/martha-nussbaum-patriotism-and-cosmopolitanism 29 November, 2013.

NUSSBAUM, M.C. (1997) 'Kant and Stoic Cosmopolitanism', Journal of Political Philosophy Vol. 5, Issue 1: p.1- 
OLOFSSON, A. \& Öhman, S. (2007) 'Cosmopolitans and Locals: An Empirical Investigation', Current Sociology Vol. 55, Issue 6: p. 877-895.

PALFREY, J. \& Gasser, U. (2008) Born Digital: Understanding the First Generation of Digital Natives Basic Books.

PHILLIPS, T. \& Smith, P. (2008) 'Cosmopolitan Beliefs and Cosmopolitan Practices: An Empirical Investigation', Journal of Sociology Vol. 44, Issue 4: p.391-399. [doi://dx.doi.org/10.1177/1440783308097128]

PICHLER, F. (2008) 'How Real is Cosmopolitanism in Europe?', Sociology Vol. 42, Issue 6: p. 1107-1126. [doi://dx.doi.org/10.1177/0038038508096936]

PICHLER, F. (2009) "Down-to-Earth' Cosmopolitanism - Subjective an Objective Measurements of Cosmopolitanism in Survey Research', Current Sociology Vol. 57, Issue 5: p.704-732. [doi://dx.doi.org/10.1177/0011392109337653]

PICHLER, F. (2012) 'Cosmopolitanism in a Global Perspective: An International Comparison of Open-Minded Orientations and Identity in Relation to Globalization', International Sociology Vol. 27, Issue 1: p.21-50. [doi://dx.doi.org/10.1177/0268580911422980]

POLLOCK, S., Bhabha, H.K., Breckenridge C.A., \& Chakrabarty, D. (2000) 'Cosmopolitanisms', Public Culture Vol. 12, Issue 3: p.577-589. [doi://dx.doi.org/10.1215/08992363-12-3-577]

RANTANEN, T. (2005) The Media and Globalization. London: Sage.

RIEFLER, P. \& Diamantopoulos, A. (2009) 'Consumer Cosmopolitanism: Review and Replication of the CYMYC Scale', Journal of Business Research Vol. 62, Issue 4: p.407-419. [doi://dx.doi.org/10.1016/j.jbusres.2008.01.041]

ROBERTSON, A. (2010) Mediated Cosmopolitanism: The World of Television News. Cambridge: Polity Press.

ROBERTSON, A. (2012) 'Media Cultures and Cosmopolitan Connections' in Delanty, G (Ed)Routledge Handbook of Cosmopolitanism Studies. London, New York: Routledge.

ROUDOMETOF, V. (2005) 'Transnationalism, Cosmopolitanism and Globalization', Current Sociology Vol. 53, Issue 1: p. 113-135. [doi://dx.doi.org/10.1177/0011392105048291]

ROUDOMETOF, V. (2012) 'Cosmopolitanism and Empirical Social Research' in Delanty, G (Ed)Routledge Handbook of Cosmopolitanism Studies. London, New York: Routledge.

SAITO, H. (2011) 'An Actor Network Theory of Cosmopolitanism', Sociological Theory Vol. 29, Issue 2: p. 124149. [doi://dx.doi.org/10.1111/j.1467-9558.2011.01390.x]

SAYRE, F. (1938) Diogenes of Sinope - A Study of Greek Cynicism. Baltimore: J.H. Furst Company.

SCHUETH, S. \& O'Loughlin, J. (2008) 'Belonging to the World: Cosmopolitanism in Geographic Contexts', Geoforum Vol. 39: p.926-941. [doi://dx.doi.org/10.1016/j.geoforum.2007.10.002]

SELWYN, N. (2009) 'Digital Native - Myth and Reality', Aslib Proceedings Vol. 61, Issue 4: p.364-379. [doi://dx.doi.org/10.1108/00012530910973776]

SKEY, M. (2012) 'We Need to Talk About Cosmopolitanism: The Challenge of Studying Openness towards Other People', Cultural Sociology Vol. 6, Issue 4: p.471-487. [doi://dx.doi.org/10.1177/1749975512445434]

SKRBIS, Z., Kendall, G., \& Woodward I. (2004) 'Locating Cosmopolitanism: Between Human Ideal and Grounded Social Category', Theory, Culture \& Society Vol. 21, Issue 6: p.115-136. [doi://dx.doi.org/10.1177/0263276404047418]

SKRBIS, Z. \& Woodward, I. (2011) 'Cosmopolitan Openness' in Rovisco, M \& Nowicka, M (Eds). (2011)The Ashgate Research Companion to Cosmopolitanism. Ashgate.

SMITH, W. (2007) 'Cosmopolitan Citizenship: Virtue, Irony and Worldliness', European Journal of Social Theory Vol. 10, Issue 1: p.37-52. [doi://dx.doi.org/10.1177/1368431006068755] 
STEVENSON, N. (2002) 'Cosmopolitanism, Multiculturalism and Citizenship', Sociological Research Online Vol. 7, Issue 1. http://www.socresonline.org.uk/7/1/stevenson.html.

SZERSZYNSKI, B. \& Urry, J. (2002) 'Cultures of Cosmopolitanism', The Sociological Review Vol. 50, Issue 4: p.461-481.

SZERSZYNSKI, B. \& Urry, J. (2006) 'Visuality, Mobility and the Cosmopolitan: Inhabiting the World from Afar', British Journal of Sociology Vol. 57, Issue 1: p.113-132. [doi://dx.doi.org/10.1111/j.14684446.2006.00096.x]

TURNER, B.S. (2002) 'Cosmopolitan Virtue: Globalization and Patriotism', Theory, Culture \& Society Vol. 19 , Issue 1: p.45-63. [doi://dx.doi.org/10.1177/026327640201900102]

VAN DER VEER, P. (2002) 'Colonial Cosmopolitanism' in Vertovec, S., \& Cohen, R (Eds) Conceiving Cosmopolitanism: Theory, Context, and Practice. Oxford: Oxford University Press.

VAN HOOFT, S. (2007) 'Cosmopolitanism as Virtue', Journal of Global Ethics Vol. 3, Issue 3: p.303-315. [doi://dx.doi.org/10.1080/17449620701728014]

VERTOVEC, S. \& Cohen, R (eds). (2002) Conceiving Cosmopolitanism: Theory, Context, and Practice Oxford: Oxford University Press.

WERBNER, P. (1999) 'Global Pathways: Working Class Cosmopolitans and the Creation of Transnational Ethnic Worlds', Social Anthropology Vol. 7, Issue 1: p.17-35. [doi://dx.doi.org/10.1017/S0964028299000026] 